\title{
GRATITUDE, SELF-ESTEEM AND OPTIMISM IN PEOPLE WITH \\ PHYSICAL DISABILITIES
}

\author{
Rini LESTARI, S.Psi., M. Si. 1* \\ Maharani FAJAR, S. Psi.(i) 2 \\ 1 Universitas Muhammadiyah Surakarta, Faculty of Psychology, mailto:rl237@ums.ac.id ,*Correspondent Author \\ 2 Universitas Muhammadiyah Surakarta, Faculty of Psychology, mailto:maharanifajar59@gmail.com
}

\begin{tabular}{|c|c|}
\hline Article history: & A b stract \\
\hline $\begin{array}{l}\text { Accepted } 25 \text { June } 2020 \\
\text { Available online } 31 \text { August } 2020\end{array}$ & $\begin{array}{l}\text { The psychological problems experienced by people with physical disabilities are feeling hopeless } \\
\text { and uncertain of their future. They feel the future will be dismal. They also feel afraid of not having }\end{array}$ \\
\hline Keywords: & proper education, jobs, and place in society, not be able to work normally, fail in lives, rejected, and \\
\hline Gratitude, & not be able to give the best to their loved ones. This condition indicates non-optimistic. Optimism is \\
\hline Optimism, & an essential psychosocial resource for protecting the health and influencing human functioning. The \\
\hline Physical Disability, & purpose of this study is to examine the relationship between gratitude and self-esteem with optimism \\
\hline Psychological Problems, & in people with physical disabilities. The samples of this study were people with physical disabilities, \\
\hline Self-Esteem. & aged 18 - 35 years old, attended social rehabilitation and totaled 106 people. Data collection methods \\
\hline & were gratitude scale, self-esteem scale, and LOT-R. Analysis of the data used multiple regression \\
\hline & $\begin{array}{l}\text { analysis. The analysis indicates that there is a significant relationship between gratitude and self- } \\
\text { esteem with optimism in people with physical disabilities. The contribution of gratitude and self- }\end{array}$ \\
\hline & $\begin{array}{l}\text { esteem variables to optimism is } 48.1 \% \text {. People with physical disabilities have optimism and gratitude } \\
\text { in the high category, while self-esteem in the medium category. }\end{array}$ \\
\hline
\end{tabular}

\section{Introduction}

The number of people with disabilities in the world is increasing, at least $10 \%$ of the population has physical, mental, social, and $80 \%$ of disabilities is in the developing countries (Forouzan, Mahmoodi, Shushtari, Salimi, 2013). World Health Organization's data (WHO, 2018) show that $15 \%$ of the world's population has physical disabilities and \pm 100 -200 million people aged \pm 13 years and above have physical disabilities. The percentage of disabilities in Indonesia also continues to increase every year. In 2018 , there are $10.2 \%$ of children aged 5-17 years and $44 \%$ at ages 18-59 years have disabilities (Kementerian Kesehatan Republik Indonesia, 2018). A large number of people with disabilities make the government need to pay more attention to assist the problems faced by people with disabilities.

There are four types categorizes people with disabilities, i.e., physical, mental, intellectual and sensory (UU RI Nomor 8 Tahun 2016). People with physical disabilities are referred as crippled, physically disabled, physically handicapped, i.e., individuals who have orthopedic and physical disabilities making it difficult to move normally (Merdiasi, 2013; Misbach, 2014). This physical disability can be owned by someone from the hereditary (congenital), or not from the hereditary (accident or illness).

Various physical, social and psychological problems are frequently experienced by people with physical disabilities. For this reason, the government provides a social rehabilitation center that provides services, rehabilitation, resocialization, and further guidance for people with physical disabilities. This social center aims to improve social, physical, psychological, mental functioning, spiritual capabilities and responsibilities of people with physical disabilities as members of the community. In this social center, people with physical disabilities are given education and various skills to live in the community. However, the imperfect physical condition still has serious psychological effects and other negative feelings. The dominant psychological problem experienced by people with physical disabilities is feeling lost, hopeless, and unsure of their future. They feel the 
future will be dismal. They also feel afraid of not having proper education, jobs, and place in society, not be able to work normally, fail in lives, being rejected, and not be able to give the best to their loved ones. This condition indicates pessimism or non-optimistic. Optimism is essential for life because it becomes a psychosocial resource to protect health and affect human functioning (Karademas, 2006; Rasmussen, Scheier, \& Greenhouse, 2009).

Optimism is a cognitive tendency to expect and predict positive outcomes (Carver \& Connor-Smith, 2010; Scheier, Carver, \& Bridges, 2001; Srivastava, Richards, McGonigal, Butler, \& Gross, 2006; Srivastava \& Angelo, 2009). Optimism is also the hope that positive events will occur in individuals (Carver, Scheier \& Segerstrom, 2010). Optimistic individuals will have positive expectations and are confident about their future. Optimism will direct human behavior to be more positive (De Vries, 2009).

Optimism is influenced by several factors including gratitude (Emmons \& McCullough, 2003) and self-esteem (Karademas, Karvelis \& Argylopoulou, 2007; Seligman, 1991). Gratitude is one of the factors, which has a positive impact on humans (Emmons, 2007). Gratitude is a feeling of gratitude and appreciation for the kindness received. Various life experiences can cause feelings of gratitude, but gratitude frequently comes from the perception that someone has received gifts or kindness from other parties (Emmons, McCullough, \& Tsang, 2003). Gratitude is done transparently to God, nature, animals, and interpersonal (Emmons \& Shelton, 2002; Ruini, 2017). Gratitude also means recognition of positive things that happen to individuals (Emmons, 2007). Gratitude occurs when someone realizes something good has happened to him and other parties are contributing and responsible for the benefits received. Something good is not only the benefits that just happened but also those that happened in the past. Good things are positive benefits that have appeared in a person's life and can eliminate unpleasant conditions (Watkins, 2014). Research shows that gratitude is a significant crucial resource for individuals (Emmons \& Shelton, 2002) and contributes to optimism (Emmons \& McCullough, 2003). Individuals who are grateful for the circumstances they receive will have positive expectations for the life to come.

Optimism is also influenced by self-esteem. Self-esteem is an evaluation of oneself and becomes one of the specific components of self-concept (Robinson, Shaver \& Wrightsman, 1991). Selfesteem concerns with how individuals perceive, feel, and respect themselves realistically (McKay \& Fanning, 2000; Schiraldi, 2007). Realistic means the individuals are dealing with the truth, accurately and honestly realizing their strengths, weaknesses, while respecting shows that the individuals have positive feelings. Self-esteem includes self-efficacy and self-respect. Self-efficacy means confidence that can think, understand, learn, choose, and self-respect means to guarantee something of value; appreciation for life and happiness; comfortable in thoughts, desires, and needs; the feeling that happiness and self-fulfillment are individual rights (Branden, 1994). Individuals who have positive self-esteem will consider failure as a challenge to face calmly when they fail so that it leads to a positive impression on their personality. It will also facilitate the resolution of other problems and cause a sense of satisfaction with themselves (Triwahyuningsih, 2017). This self-satisfaction will trigger more positive hopes for the future.

The research on optimism has been conducted on a variety of subjects but it is still rarely done on people with physical disabilities especially those related to gratitude. The purpose of this study is to examine the relationship between gratitude and self-esteem with optimism in people with physical disabilities. The hypothesis of this study is that there is a relationship between gratitude and self-esteem with optimism in people with physical disabilities.

\section{Method}

\subsection{Subjects}

The subjects of this study were people with physical or noncongenital disabilities (accidents, illness), aged 18 -35 years (average age $=25.3$ years), participated in social rehabilitation and totaled 106 people.

Table 1. Distribution of Subjects

\begin{tabular}{|c|c|c|c|}
\hline & Criteria & Total & $\%$ \\
\hline \multicolumn{4}{|l|}{ Gender } \\
\hline a. & Male & 79 & 74 \\
\hline b. & Female & 27 & 26 \\
\hline \multicolumn{4}{|c|}{ Level of education } \\
\hline a. & Elementary School & 12 & 11 \\
\hline b. & Junior High School & 26 & 25 \\
\hline c. & Senior High School & 68 & 64 \\
\hline \multicolumn{4}{|c|}{ Source of Physical Disability } \\
\hline a. & Congenital & 57 & 54 \\
\hline b. & Non-Congenital & 49 & 46 \\
\hline
\end{tabular}




\subsection{Data Collection}

The data collection of this study was the gratitude scale, selfesteem scale, and The Revised Life Orientation Test (LOT-R). LOT-R (Carver \& Scheier, 2003) was implemented to measure the level of optimism of the subject. LOT-R consists of 10 items and has a Cronbach's alpha reliability $\alpha=0.840$.

Gratitude was measured by the Indonesian version of the gratitude scale developed by Listiyandini, Nathania, Syahniar, and Nadya (2017), by integrating the Fitzgerald gratitude component (Emmons, 2004) and Watkins, Woodward, Stone, and Kolts (2003). These components are a sense of appreciation for others, God and life, positive feelings towards life owned, and a tendency to act positively as an expression of positive feelings and appreciation that is owned (behavior expression). This gratitude scale consists of 20 items and has a Cronbach's alpha reliability $\alpha=0.887$.

Self-esteem was measured using a self-esteem scale based on Coopersmith's theory, with significant, power, competence, and virtue aspects (Coopersmith, 1967). The self-esteem scale consists of 21 items and has a Cronbach's alpha reliability $\alpha=$ 0.817 .

All scales applied have reliability coefficients above 0.80 that indicate high internal consistency (Weels \& Wollack, in Azwar, 2018). Choice of answers on a scale using the method of a summated rating scale with four answer choices, i.e., Very Unsuitable (VUS), Unsuitable (US), Suitable (S), Very Suitable (VS). The term "Suitable" is used as a response choice on a scale that measures the state of the subjects so that in responding to the subject items first weigh the extent to which the contents of the statement is a description of their state or a description of their behavior (Azwar, 2012).

\subsection{Data Analysis}

Analysis of the data applied in this study was the multiple regression analysis. This analysis was selected because it will examine the correlation between two independent variables namely gratitude and self-esteem with one variable depending on optimism.

\section{Results and Discussion}

\subsection{Results}

The results of statistical analysis show the value of $R=0.693$; $p$ $=0,000(\mathrm{p}<0.01)$; which means there is a very significant relationship between gratitude and self-esteem with optimism in people with physical disabilities. These results can prove the hypothesis proposed by researchers that there is a relationship between gratitude and self-esteem with optimism in people with physical disabilities. The results of the analysis are shown in table

Table 2. Regression analysis

\begin{tabular}{lcccccc}
\hline & N & SD & Mean & R & R square & $\begin{array}{c}\text { Sig. } \\
(1 \text { tailed })\end{array}$ \\
\hline Gratitude & 106 & 7.013 & 64.34 & 0.693 & 0.481 & $0.000^{* *}$ \\
Self Esteem & & 6.121 & 61.24 & & & \\
Optimism & & 2.185 & 18.16 & & & \\
\hline
\end{tabular}

Note: $* * \mathrm{p}<0.01$

Statistical analysis also indicates that the value of $\mathrm{r} 1=0.518 ; \mathrm{p}=$ $0,000$ ( $\mathrm{p}<0.01)$; which means there is a very significant positive relationship between gratitude and optimism in people with physical disabilities. Likewise, the value of $\mathrm{r} 2=0.541 ; \mathrm{p}=0,000$
( $\mathrm{p}<0.05$ ); which means there is a very significant positive relationship between self-esteem and optimism in people with physical disabilities. The analysis results are shown in table 3 .

Table 3. Analysis of gratitude, self-esteem, and optimism correlation

\begin{tabular}{lcc}
\hline \multicolumn{1}{c}{ Variable } & $\mathrm{r}$ & Sig. (1 tailed) \\
\hline Gratitude, optimisme & 0.518 & $0.000^{* *}$ \\
Self-esteem, optimisme & 0.541 & $0.000^{* *}$ \\
\hline
\end{tabular}

Note: $* * \mathrm{p}<0.01$

The effective contribution made by the gratitude and self-esteem to optimism is $48.1 \%$, so there are still $51.9 \%$ of other variables that affect optimism. Hypothetical mean gratitude is 50, while empirical mean gratitude is 64.34 . Hence, the subject's gratitude is categorized as high. The hypothetical mean of self-esteem is 52.5 , while the empirical mean of self-esteem is 61.24 . Thus, the 
subject's self-esteem is classified as moderate. Hypothetical mean optimism is 15 , while the empirical mean of optimism is 18.16 . Hence, the optimism of research subjects is classified as high.

\subsection{Discussions}

This research proves that there is a very significant relationship between gratitude and self-esteem with optimism in people with physical disabilities. The analysis also proves a very significant positive relationship between gratitude and optimism in people with physical disabilities $(\mathrm{r}=0.518 ; \mathrm{p}<0.01)$. Correlation of gratitude and optimism is strong category (Sujarweni, 2014). This results support the research of Emmons and McCullough (2003) and Bono, Emmons, \& McCullough (2012).

Grateful individuals realize other parties have contributed to themselves and will appreciate any gift from God and other parties. People with physical disabilities understand that they have received positive treatment from caregivers, social institutions, and the government who have tried to achieve independence and improve their welbeing through maintenance, rehabilitation, social assistance, and equal opportunities. They also appreciated the government's efforts to develop public facilities that are friendly to people with physical disabilities. This acceptance and appreciation will give rise to positive feelings about their life now and in the future (Fitzgerald, in Emmons, 2004; Watkins et al., 2003). The seriousness and support of the government will foster hope that the lives of people with disabilities will be much better in the future. People with physical disabilities have confidence and hope that they will be able to move better and positive things will happen in the future so that optimism increases (Carver et al., 2010). Conversely, people with disabilities who are less aware of and appreciate the giving of other parties will still emerge negative feelings and feel marginalized so that they tend to be pessimistic and uncertain of their lives in the future.

Gratitude is done when there is an acknowledgment that something positive has happened to the individual (Emmons, 2007). Grateful individuals will thank and appreciate the goodness of others' interpersonal and transpersonal (Emmons et al., 2003). This feeling can lead to a life orientation of someone who pays more attention to positive things (Wood, Froh, \& Geraghty, 2010) so that they will have positive hopes for the life to come (Emmons \& McCullough, 2003). People with physical disabilities can be grateful because they can still accomplish their daily activities independently even though their physical conditions are imperfect such as having no hands, feet, and so on. They feel that this condition is a gift from God and believe there is a better plan for God so that they remain optimistic about their future. Whereas people with physical disabilities who are less grateful will feel that they are not worthy to live in the world, because they will only distress others and their surroundings so they do not have positive hopes for their future.

This study also proves that there is a very significant positive relationship between self-esteem and optimism in people with physical disabilities $(\mathrm{r}=0.541 ; \mathrm{p}<0.01)$. Correlation of selfesteem and optimism is strong category (Sujarweni, 2014). This result supports the research of Purba (2017) and Mulawarmani, Nugroho, Susilawati, Afriwilda, Kunwijaya (2019). Selfesteem is an individual's evaluation of oneself (Amirazodi \& Amirazodi, 2011; Robinson et al., 1991). Individuals who have high self-esteem will be more willing to take risks to achieve goals despite the possibility of failure. However, individuals with low self-esteem tend to fear being rejected in the pursuit of success and prestige, avoiding risks that make situations difficult for themselves (Baumeister, Campbell, Krueger, \& Vohs, 2003). Thus individuals who have high self-esteem will increase the probability of success, reduce the effects of failure to develop optimism (Bastianello, Pacico, \& Hutz, 2014; Campbell, Chew, \& Scratchley, 1991).

Optimistic individuals have sufficient self-esteem characteristics, tend to accept themselves as carriers of positive characteristics that are socially desirable, and have a high level of self-control (Tsivilskaya \& Artemyeva, 2016). Individuals who have high self-esteem will respect themselves so that they have positive feelings because they believe in their abilities realistically and feel happy with the fulfillment of their rights (Branden, 1994). People with physical disabilities who have high self-esteem will respect themselves and have confidence that they are valuable. They can accept and forgive themselves for all the shortcomings and imperfections they have. They will not feel down when being criticized. These positive beliefs and feelings will influence attitudes and behaviors to be more optimistic about the future. Optimistic individuals hope that positive events will occur (Carver et al., 2010). It happens because optimistic individuals are frequently more willing to face daily challenges and believe in having the power to overcome challenges by trying to increase their strength and use innovative thinking to achieve success (Seligman, 1991).

Gratitude and self-esteem contribute $48.1 \%$ so there are $51.9 \%$ other variables that affect optimism. Variables that can affect optimism include interest, motivation, self-confidence, successful experiences (Seligman, 1991), age, parity status, marital status, health status, education level, family support, stress, coping, selfefficacy (Karademas et al., 2007; Mosing et al., 2009) and socioeconomic status (Carver et al., 2010). 
The results of this study indicate that the level of optimism of people with physical disabilities is relatively high. It can be high since people with physical disabilities have attended education in social rehabilitation institutions so that they already have the skills to make a living as the main goal of the adult subjects. Their skills range from photography, workshop, carpentry, computer, sewing, food, and beauty. Social institutions also provide internship opportunities in government and private institutions to provide practical opportunities and increase their confidence. Some people with disabilities have also successfully worked in government and private institutions. It is an example for other people with disabilities and motivates them to be able to reveal work and have a better life in the future.

One factor that can increase optimism is social support (Seligman, 1991). Social support can be provided in the form of emotional, appreciation, instrumental, and information support (Sarafino, 2006). People with physical disabilities obtain attention, guidance, education, appreciation, information, and physical-social facilities that can provide a more positive sense of security and hope for their future. The government also provides opportunities for people with physical disabilities to obtain equal access to education, health, political, technology, information, communication, and better employment opportunities in the formal and informal sectors. Government programs that plan to establish factories that employ and are managed by people with physical disabilities convince them to enjoy the rights without discrimination. People with disabilities also obtain full support from the government with affirmative programs in the form of providing disability cards, individual assistance, social assistance, and independence. The government also gave bonuses to athletes who got or did not get the medals at the 2018 Asian Games as a form of respect and appreciation for all the dedication and struggle of athletes for the nation and state. This opportunity strengthens the belief of people with physical disabilities that they have good opportunities in the future.

The gratitude of people with physical disabilities is also high because they feel fortunate to have the opportunity to get free education, skills, and physical needs provided by the government. When they graduate, they also obtain capital equipment to work such as cameras, sewing machines, and beauty equipment. They understand that not all people with physical disabilities got the opportunity that they obtained so far. Religious studies are also conducted routinely so that people with physical disabilities get continuous spiritual learning. This repetitive information will strengthen the subjects to continue to be grateful for gifts given by God (they are healthy, and able to see so they can learn compared to others) or from others (attention, nursing/government facilities, education, clothing, equipment, shelter, friends, caregivers and so on). Various life experiences received by these individuals can cause feelings of gratitude (Emmons et al., 2003). The more positive experiences, the higher the gratitude.

Self-esteem is one of the most crucial aspects of personality that can shape identity and affect all life (Mulawarmani et al., 2019). Therefore, it needs to be improved in various ways. One of the ways undertaken by the government is a commitment to realize disability equality, build an inclusive and disability-friendly, and encourage more participation and active participation in development. However, these efforts have not been able to make the dignity of people with physical disabilities high. Their selfesteem is moderate because the physical condition is still a major concern. People with physical disabilities tend to compare their physicality with others when they first meet and sometimes they still have doubts about the acceptance of others because of their imperfect physical condition. Several studies also identified that the most essential component and the main predictor of selfesteem is social acceptance and physical appearance in men and women at all age levels (Shapka \& Keating, 2005).

The process of forming self-esteem starts with the interaction of individuals with their environment. In their interactions with other people, individuals try to know themselves and others. The picture of themselves will form an organized concept within the individuals. The concept will form a self-image that is the overall perception of the quality, abilities, encouragement, and attitudes they have in interacting with others. It will further shape selfesteem (Rosenberg, 1989). Self-esteem is influenced by internal factors such as the capacity to love, rationally thinking, the state of one's body (appearance, vitality, and health, mood, performance, level of expertise, and control over events) (Schiraldi, 2007), personality trait (Amirazodi \& Amirazodi, 2011), and mindfulness (Pepping, O'Donovan, Davis, 2013). External factors that influence self-esteem are demographic conditions (economic status, sex, race, age), respect, family relationships, popularity (Schiraldi, 2007), parenting models, social environment, academic success, social status (McKay \& Fanning, 2000), feedback from significant people, family disputes and disorders (Mann, Hosman, Schaalma \& de Vries, 2004), gender equality and cultural values (Bleidorn, Arslan, Denissen, Rentfrow, Gebauer, Potter, 2016) and physical exercise (Liu, Wu, Ming, 2015).

The self-esteem of people with physical disabilities still needs to be improved because it is highly crucial for health, the ability to overcome problems, survive, and health (Schiraldi, 2007). Selfesteem is also a strong motivation to work hard, enhance wellbeing, happiness, adjustment, success, satisfaction and academic 
achievement (Schiraldi, 2007); improve performance, personal relationships, health and a healthy lifestyle (Baumeister et al., 2003); marital satisfaction (Homaei, Bozorgi, Ghahfarokhi \& Hosseinpour, 2016). Individuals who lack self-esteem are more likely to experience depression, anxiety, poor social functioning, risky behavior, eating disorders, drop out (Mann et al., 2004), anger, chronic pain, decreased immunity, fear to initiate friendships, avoid social contact, incline to isolate, scare to express opinions, act recklessly, passive, aggressive and selfdestructive and various other physical and psychological symptoms that are troublesome (Schiraldi, 1999, 2007).

\section{Conclusion}

People with physical disabilities frequently feel hopeless and less optimistic about their future, whereas optimism plays an essential role in human health. The optimism of people with physical disabilities can be influenced by gratitude and self-esteem. This research proves a very significant relationship between gratitude and self-esteem with optimism in people with physical disabilities. The contribution of gratitude and self-esteem variables to optimism is $48.1 \%$ so there are still $51.9 \%$ of other variables that influence optimism, such as interests, motivation, self-confidence, success experiences, age, parity status, marital status, health status, education level, family support, stress, coping, self-efficacy and socioeconomic status. People with physical disabilities have optimism and gratitude in the high category, while their self-esteem is in the medium category.

\section{Acknowledgement}

We thank to Universitas Muhammadiyah Surakarta and BBRSPDF [Balai Besar Rehabilitasi Social Penyandang Disabilitas Fisik], for providing permissions for us to conduct the research. This research receives a specific grant from Universitas Muhammadiyah Surakarta.

\section{References}

1. Amirazodi, F., \& Amirazodi, M. (2011). Personality traits and Self-esteem. Procedia - Social and Behavioral Sciences, 29, 713-716. https://doi.org/10.1016/j.sbspro.2011.11.296

2. Azwar, S. (2012). Penyusunan skala psikologi (2nd ed.). Yogyakarta : Pustaka Pelajar.

3. Azwar, S. (2018). Reliability and validity (4th ed.). Yogyakarta : Pustaka Pelajar.

4. Bastianello, M. R., Pacico, J. C., \& Hutz, C. S. (2014). Optimism, self-esteem and personality: adaptation and validation of the Brazilian Version Of The Revised Life Orientation Test (LOT-R). Psico-USF, 19(3), 523-531. https://doi.org/10.1590/1413-827120140190030
5. Baumeister, R. F., Campbell, J. D., Krueger, J. I., \& Vohs, K. D. (2003). Does high self-esteem cause better performance, interpersonal success, happiness, or healthier lifestyles? Psychological Science in the Public Interest, 4(1), 1-44. https://doi.org/10.1111/1529-1006.01431

6. Bleidorn, W., Arslan, R. C., Denissen, J. J. A., Rentfrow, P. J., Gebauer, J. E., Potter, J., \& Gosling, S. D. (2016). Age and gender differences in self-esteem: A crosscultural window. Journal of Personality and Social Psychology, 111(3), 396-410. https://doi.org/10.1037/pspp0000078

7. Bono, G., Emmons, R. A., \& McCullough, M. E. (2012). Gratitude in Practice and the Practice of Gratitude. In P. A. Linley \& S. Joseph (Eds.), Positive Psychology in Practice (pp. 464-481). New Jersey : John Wiley \& Sons, Inc. https://doi.org/10.1002/9780470939338.ch29

8. Branden, N. (1994). The six pillars of self-esteem. New York : Bantam Books, Inc.

9. Campbell, J. D., Chew, B., \& Scratchley, L. S. (1991). Cognitive and emotional reactions to daily events: The effects of self-esteem and self-complexity. Journal of Personality, 59(3), 473-505. https://doi.org/10.1111/j.1467-6494.1991.tb00257.x

10. Carver, C. S., \& Connor-Smith, J. (2010). Personality and coping. Annual Review of Psychology, 61(1), 679-704. https://doi.org/10.1146/annurev.psych.093008.100352

11. Carver, C. S., \& Scheier, M. (2003). Optimism. In S. J. Lopez \& C. R. Snyder (Eds.), Positive psychological assessment: A handbook of models and measures. (pp. 7589). Washington DC : American Psychological Association. https://doi.org/10.1037/10612-005

12. Carver, C. S., Scheier, M. F., \& Segerstrom, S. C. (2010). Optimism. Clinical Psychology Review, 30(7), 879-889. https://doi.org/10.1016/j.cpr.2010.01.006

13. Coopersmith, S. (1967). The antecendents of selfesteem. San Francisco : W. H. Freeman and Company.

14. De Vries, M. F. R. K. (2009). The happiness equation. Meditations on happiness and success. Lincoln : iUniverse. 15. Emmons, R. A. (2004). The Psychology of Gratitude. In R. A. Emmons \& M. E. McCullough (Eds.), The Psychology of Gratitude (pp. 3-16). New York: Oxford University

Press. https://doi.org/10.1093/acprof:oso/9780195150100.003.00 $\underline{01}$

16. Emmons, R. A. (2007). Thanks! How the new science of gratitude can make you happier. New York : HoughtonMifflin.

17. Emmons, R. A., \& McCullough, M. E. (2003). Counting blessings versus burdens: An experimental investigation of gratitude and subjective well-being in daily 
life. Journal of Personality and Social Psychology, 84(2), 377-389. https://doi.org/10.1037/0022-3514.84.2.377

18. Emmons, R. A., McCullough, M. E., \& Tsang, J.-A. (2003). The assessment of gratitude. In S. J. Lopez \& C. R. Snyder (Eds.), Positive psychological assessment: A handbook of models and measures. (pp. 327-341). Washington DC : American Psychological Association. https://doi.org/10.1037/10612-021

19. Emmons, R. A., \& Shelton, C. M. (2002). Gratitude and the science of positive psychology. In C. R. Snyder \& S. J. Lopez (Eds.), Handbook of positive psychology (pp. 459-471). Oxford : Oxford University Press.

20. Forouzan, S. A., Mahmoodi, A., Jorjoran Shushtari, Z., Salimi, Y., Sajjadi, H., \& Mahmoodi, Z. (2013). Perceived social support among people with physical disability. Iranian Red Crescent Medical Journal, 15(8), 663-667. https://doi.org/10.5812/ircmj.12500

21. Homaei, R., Bozorgi, Z. D., Ghahfarokhi, M. S. M., \& Hosseinpour, S. (2016). Relationship between optimism, religiosity and self-esteem with marital satisfaction and life satisfaction. International Education Studies, 9(6), 53. $\underline{\text { https://doi.org/10.5539/ies.v9n6p53 }}$

22. Karademas, E. C. (2006). Self-efficacy, social support and well-being. Personality and Individual Differences, 40(6),

1281-1290.

\section{https://doi.org/10.1016/j.paid.2005.10.019}

23. Karademas, E. C., Karvelis, S., \& Argyropoulou, K. (2007). Stress-related predictors of optimism in breast cancer survivors. Stress and Health, 23(3), 161-168. https://doi.org/10.1002/smi.1132

24. Kementerian Kesehatan Republik Indonesia. (2018). Hasil utama riskesdas 2018. http://kesmas.kemkes.go.id/assets/upload/dir 519d41d8cd 98f00/files/Hasil-riskesdas-2018 1274.pdf

25. Listiyandini, R. A., Nathania, A., Syahniar, D., Sonia, L., \& Nadya, R. (2015). Mengukur rasa syukur: Pengembangan model awal skala bersyukur versi Indonesia. Jurnal Psikologi Ulayat, 2(2), 473-496. https://doi.org/10.24854/jpu22015-41

26. Liu, M., Wu, L., \& Ming, Q. (2015). How does physical activity intervention improve self-esteem and selfconcept in children and adolescents? evidence from a metaanalysis. PLOS ONE, 10(8), 1-17. https://doi.org/10.1371/journal.pone.0134804

27. Mann, M., Hosman, C. M. H., Schaalma, H. P., \& de Vries, N. K. (2004). Self-esteem in a broad-spectrum approach for mental health promotion. Health Education Research, 19(4), 357-372. https://doi.org/10.1093/her/cyg041
28. McKay, M., \& Fanning, P. (2000). Self-Esteem: A Proven program of cognitive tecniques for assessing, improving and maintaning your self-esteem. Oakland, CA : New Harbinger Publications, Inc.

29. Merdiasi, D. (2013). Gambaran tuna daksa yang bekerja. Jurnal Noetic Psychology, 3(2), 163-184.

30. Misbach, D. (2014). Seluk beluk tunadaksa \& strategi pembelajarannya. Yogyakarta : Javalitera.

31. Mosing, M. A., Zietsch, B. P., Shekar, S. N., Wright, M. J., \& Martin, N. G. (2009). Genetic and environmental influences on optimism and its relationship to mental and self-rated health: A study of aging twins. Behavior Genetics, 39(6), 597-604. https://doi.org/10.1007/s10519009-9287-7

32. Mulawarmani, M., Nugroho, I. S., Susilawati, S., Afriwilda, M. T., \& Kunwijaya, I. (2019). Enhancing selfesteem and optimism based on flipped classroom guidance on undergraduate counseling student in Indonesia. European Journal of Education Studies, 6(5), 263-273. https://doi.org/10.5281/zenodo.3382157

33. Pepping, C. A., O’Donovan, A., \& Davis, P. J. (2013). The positive effects of mindfulness on self-esteem. The Journal of Positive Psychology, 8(5), 376-386. https://doi.org/10.1080/17439760.2013.807353

34. Purba, A. W. D. (2017). The correlation between selfesteem and optimism for the recovery of hemodialysis patient in the Dr. H. Kumpulan Pane Hospital. IOSR Journal Of Humanities And Social Science (IOSR-JHSS), 22(10), 71-81. https://doi.org/10.9790/0837-2210017181

35. Rasmussen, H. N., Scheier, M. F., \& Greenhouse, J. B. (2009). Optimism and physical health: A meta-analytic review. Annals of Behavioral Medicine, 37(3), 239-256. https://doi.org/10.1007/s12160-009-9111-X

36. Robinson, J. P., Shaver, P. R., \& Wrightsman, L. S. (1991). Measures of personality and social psychological attitudes. California : Elsevier/Academic Press. https://doi.org/10.1016/C2013-0-07551-2

37. Rosenberg, M. (1989). Society and the adolescent self-image. Middletown, CT : Wesleyan University Press. 38. Ruini, C. (2017). Positive psychology in the clinical domains. Springer International Publishing. https://doi.org/10.1007/978-3-319-52112-1

39. Sarafino, E. P. (2006). Health psychology: Biopsychological Interactions (5th ed.). New York : John Wiley \& Sons, Inc.

40. Scheier, M. F., Carver, C. S., \& Bridges, M. W. (2001). Optimism, pessimism, and psychological wellbeing. In E. C. Chang (Ed.), Optimism \& pessimism: Implications for theory, research, and practice. (pp. 189- 
216). Washington DC : American Psychological Association. https://doi.org/10.1037/10385-009

41. Schiraldi, G. R. (1999). Building self esteem: A 125 day program. Ellicott City : Chevron Pub Corp.

42. Schiraldi, G. R. (2007). 10 Simple solutions for building self-esteem: How to end self-doubt, gain confidence $\&$ create a positive self-image. Oakland, CA : New Harbinger Publications, Inc.

43. Seligman, M. E. P. (1991). Learned optimism. New York : Knopf.

44. Shapka, J. D., \& Keating, D. P. (2005). Structure and change in self-concept during adolescence. Canadian Journal of Behavioural Science / Revue Canadienne Des Sciences Du Comportement, 37(2), 83-96. https://doi.org/10.1037/h0087247

45. Srivastava, S., \& Angelo, K. M. (2009). Optimism, effects on relationships. In Encyclopedia of human relationships. Thousand Oaks, CA : Sage.

46. Srivastava, S., McGonigal, K. M., Richards, J. M., Butler, E. A., \& Gross, J. J. (2006). Optimism in close relationships: How seeing things in a positive light makes them so. Journal of Personality and Social Psychology, 91(1), 143-153. $\quad$ https://doi.org/10.1037/0022$\underline{3514.91 .1 .143}$

47. Sujarweni, V. W. (2014). SPSS untuk penelitian. Yogyakarta : Pustaka Baru Press.

48. Triwahyuningsih, Y. (2017). Kajian Meta-Analisis Hubungan antara Self Esteem dan Kesejahteraan Psikologis. Buletin Psikologi, 25(1), 26-35. https://doi.org/10.22146/buletinpsikologi.9382

49. Tsivilskaya, E. A., \& Artemyeva, T. V. (2016). The study of optimism and positive self-concept of students. International Journal of Humanities and Cultural Studies (IJHCS),

1618-1624.

https://www.ijhcs.com/index.php/ijhcs/article/view/2105

50. UU RI No. 8 Tahun (2016) [Undang-Undang Republik Indonesia Nomor 8 Tahun 2016 tentang Penyandang Disabilitas]. http://www.dpr.go.id/dokjdih/document/uu/1667.pdf

51. Watkins, P. C. (2014). Gratitude and the good Life: Toward a psychology of appreciation. New York : Springer Netherlands. https://doi.org/10.1007/978-94-007-7253-3

52. Watkins, P. C., Woodward, K., Stone, T., \& Kolts, R.

L. (2003). Gratitude and happiness: Development of measure of gratitude and relationship with subjective wellbeing. Social Behavior and Personality, 31(5), 431-451. https://doi.org/10.2224/sbp.2003.31.5.431

53. Wood, A. M., Froh, J. J., \& Geraghty, A. W. A. (2010). Gratitude and well-being: A review and theoretical integration. Clinical Psychology Review, 30(7), 890-905. https://doi.org/10.1016/j.cpr.2010.03.005

54. World Health Organization [WHO]. (2018). Disability and health. https://www.who.int/newsroom/fact-sheets/detail/disability-and-health 55. 